\title{
Re-thinking Educational Leadership: exploring the impact of cultural and belief systems
}

\author{
Saeeda Shah, University of Leicester
}

\begin{abstract}
The paper argues that people from diverse ideological and ethnic backgrounds conceive, perceive and practise educational leadership differently, drawing upon their beliefs, values and knowledge sources. It draws on data collected from female heads of 'girls-only' colleges in a region in Pakistan. The paper briefly introduces leadership as a concept formulated in context. It presents philosophical and theoretical underpinnings of these conceptualizations from an Islamic perspective as a case, and highlights the interplay between belief systems, educational leadership and gender informed by the data and wideranging literature. The paper deliberates how these discourses interact to formulate 'educational leadership' in Muslim societies, and explores the implications of these constructions for women in educational leadership in a Muslim society. The paper highlights the impact of cultural and belief systems on notions and practices in the field of educational leadership.
\end{abstract}

Educational leadership is being defined and theorised in multiple ways to encapsulate the concepts, practices and perceptions in diverse contexts. However, theories and practices related to education in general and educational leadership in particular are predominantly ethnocentric, embedded in Western philosophy and values (Dimmock 2000). Myriad definitions (Yukl 1998), and numerous theories of leadership (Richmon and Allison 2003) that are presented in the literature, are predominantly reflective of Western perspectives. Secondly, gender is often not confronted in leadership theories 'on the assumption that leadership styles and administrative contexts are gender neutral' (Blackmore 1995, p. 103). The questions that arise here are two-pronged. First:

- Is there a hidden assumption that Western leadership concepts are applicable to all contexts; thus signalling a negation of knowledge and knowledge-sources other than ethnocentric for informing theory and practice? Or,

- Does this point to an unwillingness to take up the challenges of exploring, understanding, analysing and theorising conceptual variations and complex constructs?

Second:

- Is gender no longer an issue in educational leadership in the Western world? And,

- Is it being assumed that gender is no longer an issue in educational leadership in all societies and cultures?

With increasing diasporas of communities of diverse cultures, ideologies, and faiths, it becomes highly significant to understand how educational leadership is understood and informed by different cultural and belief systems, and how gender is experienced in educational leadership positions in different societies. This paper draws attention to a knowledge gap in existing literature regarding educational leadership theory and practice as understood and informed by different belief systems - an issue which is foreseen as gaining higher significance with the fast changing population structures across the world. My argument is that educational leadership concepts, theories and 
practices evolve in context informed by cultural and belief systems (Shah 2006b). With the changing societal structures, it becomes a prerequisite to work towards developing complex theoretical constructs to re-conceptualize educational leadership, drawing from perspectives held by diverse cultural and faith communities. Culture as a category of analysis in this field has received some attention, but significance of faith is still not acknowledged. The need is to recognise that people from diverse philosophical, ideological and faith backgrounds conceive and perceive educational leadership differently, particularly across the gender divide, drawing upon their beliefs, values and knowledge sources (Shah 2006a). This has implications for how leadership is exercised and practised in diverse cultural and faith communities. Understanding difference and working with it is a challenge as Derrida (Derrida 1976) argues by problematising 'difference', and pointing to the possibilities of multiple shifts of meaning and the subsequent implications. Derrida emphasizes that meaning of a 'sign' exists in relation to other things. If meaning is not 'present' within the sign, and if signs instead signify in relation to other things, haven't we been hanging on to misconceptions and misconstructions in the field of educational leadership?

The paper debates philosophical and theoretical underpinnings of leadership conceptualizations and practices from an Islamic perspective as a case, highlighting the complex interplay between belief systems and educational leadership, with a focus on gender. This is primarily a conceptual paper, but also draws partly on direct data collected from a qualitative study carried out in one region in Pakistan known as Azad Jammu and Kashmir (AJK). AJK is one of the five major geographical regions in Pakistan with many shared and some distinctive cultural features, and own provincial government (Niaz 1992). This region was selected for the study first because no study of women in educational leadership had ever been carried out in that part of Pakistan, and second because this author had worked in that region in higher education for a long time and had the opportunities of access. The sample included heads of all sixtyeight single-sex colleges - both male and female - in AJK. The data was collected using a semi-structured questionnaire to all the colleges heads, and twenty-eight oneto-one interviews (ten with female and fourteen with male college heads, and four with senior educational leaders including one female), followed by two mixed-sex group discussions. However, the data used in this paper is drawn from the questionnaires completed by the women college heads, from the eleven interviews with the female participants, and from the women participants' contributions to the two mixed-sex group-discussions. The decision to draw upon the data collected from the female participants only for the purposes of this paper is underpinned by the stance that:

The view point of the concrete other emerges as a distinct one only as a result of self-definition. It is the other who makes us aware of her concreteness and her otherness. Without engagement, confrontation, dialogue, and even a 'struggle for recognition' [sic] we tend to constitute the otherness of the other by projection and fantasy or ignore it in indifference. (Ben-Habib 1992, p.168) 


\section{Cultural/Belief Systems and Educational Leadership}

The concepts of educational leadership and practices vary across societies and cultures. Different interpretations of leadership reflect ways of seeing and the philosophical and theoretical assumptions behind them. Variations in interpretation arise also because in different societies not only the philosophical anchoring of conceptualisations vary, but also because 'leadership derives power and influence from different formal or informal sources of position, person, knowledge, and wisdom' (Mullins 1995, p.229, also Busher 2006, Sergiovanni 1984). How a particular society perceives and constructs educational leadership is influenced by the dominant cultural and belief systems prevailing in that society or community.

Culture and the ethos of leadership 'differ in fundamental ways across nations' (Fullan 1992, p.viii). Pugh and Hickson discuss education as a 'deeply cultural institution' (2003, p.11) where theory and practice are shaped by the values, beliefs, ideologies, behaviour and conventions in that social system. Child (2003) makes a similar argument, using the Weberian framework of formal rationality and substantive rationality to explain the impact of ideational systems (cultural, religious and political) on social institutions, placing education on the top (p.42). Weber explicates relationships between religious belief, individual attitudes and values, and social action. He defines religion as a cultural system (1963), and points to its role in determining 'action' on social (and educational) sites. He argues that 'social action' is conceptualised and enacted in different institutions determined by ideational systems - the way a community perceives reality. Weber explains the concept of religion as a system of symbols and beliefs, which via its effects on the consciousness of the believer can decisively mould and direct the content of social action (Weber, 1963). Recognising the role of material interests, he emphasises the impact of ideational systems:

Not ideas, but material and ideal interests, directly govern men's (sic) conduct. Yet very frequently the 'world images' that have been created by 'ideas' have, like switchmen, determined the tracks along which action has been pushed by the dynamic of interest. (1958, p.280)

The extent to which religious belief systems influence social action is determined by the role a religion or belief is accorded in a community. Geertz (1973) explains religion as a meaning-making process which guides men (sic) and helps them to give meaning to their existence. A religion is broadly speaking, a set of beliefs and practices generally held by a human community, involving adherence to certain beliefs and rituals. Members of that faith community participate in related activities informed by their ideological and cultural knowledge - transmitted from generation to generation, and learned through living and sharing as its member. It is this 'tacit knowledge' (Polanyi, 1967) gained and internalised through 'habitus' (Bourdieu, 1977) that guides perceptions and actions.

Many recent studies have explored the interplay between culture and leadership. Hofstede's landmark study, which focuses on business management, highlights the relationship between culture and leadership practices, citing examples from diverse societies to draw attention to the effect of societal culture on leadership concepts and practices (Hofstede 2001). Walker and Dimmock (2002), discussing the impact of 
societal and organizational cultures on leadership theory and practice in education, argue that the notion of educational leadership is formed in the backdrop of values, patterns of behaviour and ideologies of a community. In Muslim societies, education and educational leadership are influenced by the religious teachings deriving from the sacred texts, as is the case with many other belief systems. For example, the patriarchal notion of leadership and its moral dimension in China draws its power and responsibilities from the social ideology drawn from Confucius, and functions within that value system (Tung 2003, Wong 2001). In Buddhist society, 'six essential virtues of the Bodhisattva code of the Mahayana Buddhist wisdom tradition: generosity, discipline, patience, joyous effort, meditation and wisdom' (McClain 2007, p.1) play an important role in defining leadership role and practices. In Shinto ideology, leadership power derives from the notion of family as the main mechanism by which traditions are preserved (Ono 1962).

The post-modern world is experiencing a religious resurgence (Ahmed and Donnan 1994, Bauman 1997, Esposito 2002) drawing attention to the potential role of belief systems in shaping and controlling human activities in different fields. In education, there is a growing recognition of the impact of diverse cultures, values and religious beliefs on leadership practices. However, the field of education tends to avoid engaging with faith and its interplay with culture as a category of influence with regard to how leadership is understood and exercised.

\section{$\underline{\text { Islam, Educational Leadership and Gender }}$}

Educational leadership in Islam derives from Islamic philosophy of education, informed by the religious texts (Abdullah 1982, p.43), which reinforces the interplay between faith and conceptualisations/practices. The Islamic philosophy of education draws from the belief that God, the ultimate knower, 'taught to man the knowledge of things' (the Quran, 96:1-5). This raises knowledge and knowledge-sharing to the level of divine activity:

God will raise in ranks those of you who believe as well as those who are given knowledge. (The Quran, 58:11)

The prophets, otherwise ordinary human beings, have elevated status in Islamic theology because of their knowledge (The Quran, 27:15; 2:247). People of knowledge and learning guide the learners nearer to God and are attributed the highest status as the 'heirs of prophets' (Al-Bukhari, Vol-1). This association between religion and knowledge creates a discourse of educational leadership, which elevates it to a sacred duty of the highest order (Shah 1999 Talbani 1996).

The emphasis in Islam is on learning for all (Al-Attas 1979, Ashraf 1995) irrespective of gender, and other variants (the Quran, 49:13). In practice, female access to education is constrained in many Muslim societies (Griffin 2006), confining them to the domestic, with implications for their leadership role. This is where religion is interpreted differently within different societies, leading to gendered conceptualisations. Discourses of gender are located in cultural settings and national contexts. Any discussion of women in educational leadership that ignores important factors such as cultural differences, economic and social-political divisions, race and nationality, religion and identity would not only be unrealistic but may present a distorted picture' (Oplatka 
and Hertz-Lazarowitz 2006, p. 3). The discourse of 'female leadership' is determined not simply by the biological gender (Blackmore 1999, Oplatka 2001, Reay and Ball, 2000), but by how biological gender is constructed in a particular society at a particular time in history. How gender is constructed and experienced in the Muslim society of Pakistan is linked to the country context:

The social and cultural context of Pakistani society is predominantly patriarchal. Men and women are conceptually divided into two separate worlds. Home is defined as a woman's legitimate ideological and physical space, while a man dominates the world outside the home. The false ideological demarcation between public and private, inside and outside worlds is maintained through the notion of honour and institution of purdah in Pakistan. Since the notion of male honour and izzat (honour) is linked with women's sexual behaviour, their sexuality is considered a potential threat to the honour of the family. Therefore, women's mobility is strictly restricted and controlled through the system of purdah, sex segregation, and violence against them. (ADB 2000, p.2)

In the broadly segregated society of Pakistan, single-sex institutions are projected as an important feature of Muslim culture which has led to the development of two almost separate sectors of education - male (mardana) and female (zanana). Women generally have marginal participation in mixed-sex settings and institutions. Accordingly, the positions of leadership occupied by them are either tokenistic, or gender-specific or in the women-only institutions. This sex-segregation provides women a context to exercise leadership in an 'infiltration-free zone', but this also raises questions regarding female participation on desegregated sites and its implications for more public female leadership roles.

Moreover, religion in this case, acts as a determining factor in how gender roles are inscribed in private and public and how discourses are legitimised. This has similarities with many Muslim societies, such as the Arab states where similar systems of segregation prevail (Kirdar 2006). The argument is that discourses are never free of history, power and interests (Foucault 1980, p. 131). Muslim women experience 'marginality both in their professions and in the public mind' (Curry 2000, p. 4), at the interstices of faith and societal culture, which need to be explored to understand how leadership is informed by cultural/belief systems.

This paper therefore attempts to present perspectives of Muslim women educational leaders, coming from a specific region, supported by a wide range of international literature. Women's lives in Pakistan itself do not form a homogeneous entity. Depending on geographical location, a Pakistani woman can be 'a highly qualified and self-confident professional or a modest domesticated housewife, leading an extremely isolated life cut off from all decisions and information' (Qureshi 2004, p. 3 ). The nature of female leadership role and women leaders experiences are influenced by the situated framework of the social structure and its ideological basis that determine sex roles, organisational practices, and power relations. The discussion focuses on dominating discourses in Islam such as sex-roles, family, segregation/veiling, and moral code/Izzat, and explores their implications for women educational leaders and leadership conceptualisations. The aim is to highlight the 
interplay of cultural and belief systems in determining how leadership is understood and conceptualised.

\section{Sex Roles and Educational Leadership}

Doing an analysis of 180 countries from 1975 to 2000, Gray et al (2006) argue that 'gender is one of the few modes of differentiation that has social, cultural, political, and economic implications everywhere in the world' (p. 294). In countries such as America (Ozga 1994), India (Nayyer 1985), New Zealand (Strachan 1993), Britain (Wilson 1995), Europe (Wilson 1997) and the Third World (Davies 1992) it may be diverse factors interacting at different levels to define sex roles for women. Nevertheless, common to all societies and cultures seems to be an implicit belief that male/female difference implies female association with domestic, nurturing, caring roles. In Muslim societies also there is 'a general identification of women with the sphere of domesticity' (Afshar 1987, p. 3), achieved through emphasising the verses highlighting women's nurturing role towards the family (the Quran, Sura 4). Many Muslim female writers (Afshar 1987, Ahmed 1992, Al-Hibri 1982, Badawi 1994; Mernissi 1991, El Saadawi 1989) argue that this association between women and domesticity is a feudal patriarchal interpretation of religious texts:

Patriarchy co-opted Islam after the death of the prophet - many passages in the Quran were interpreted by patriarchy loosely and out of context, in support of a vicious patriarchal ideology. These interpretations were then handed down to women as God's revealed words. (Al-Hibri 1982, p. viii)

The Quran being the core of religious knowledge and the main source 'to produce, legitimise, and operationalize truth in a Muslim society' (Nasr 1981, p. 49), power lies with those who have control over religious interpretations. The Arab society, where Islam was first introduced, was a highly patriarchal society. Later Muslim societies, in spite of the Quranic teachings to the contrary, marginalised women, often constraining them to the domestic, as has been the case generally with feudal patriarchal cultures. The Quran is explicit about women being masters of their own possessions and earnings, saying that, 'Unto men a fortune from that which they have earned, and unto women a fortune from that which they have earned' (4:32), clearly pointing to options of performing in the public space. However, this participation is constrained in most Muslim societies in the name of religion, confining women either to domestic roles, limiting them to supportive roles, or redefining the professional role with gender connotations as in the case of women educational leaders.

Gender-specific socialisation constrains roles for males and females. Deriving from the wider societal cultures, positions of power and authority are viewed as genderspecific (Adler et el 1993, Davies 1992, Hall 1996, Kirdar 2006, Ouston 1993, Ozga 1994, Shakeshaft 1991, Strachan 1993). Women who are leaders are 'seen as being in the wrong place' (Gold 2006). They are stereotyped negatively as leaders and managers, and are often pre-judged as failures:

$[\mathrm{M}] \mathrm{en}$ are assumed to possess any necessary competence, until such time as they demonstrate otherwise, but women need most positively to establish the fact of their competence before this will be recognised' (Spencer and Podmore 1987, p.134) 
Gender emerges as a significant force in determining organisational roles, influenced by multiple factors such as culture, religion, ideology, socio-economic systems and many others (Ahmed 1992, hooks 1990, Ouston 1993). Gender is 'a structuring code as well as cultural expression' (Hey and Bradford2004, p.698). When women are in leadership roles, 'psychological phenomenon caused by cultural beliefs and societal attitudes of how women should behave and what role they should play' (Farouk 2006, p.444) becomes a burden to manage. Skeggs contends that:

... positioned as members of a social group with a fixed identity, rather than as individuals who perform an identity, the agency and autonomy of women workers is always limited by the social category of gender. (2004, p.55)

The public/private and nature/culture divides, underpinned by histories of feudal patriarchal cultures, scribe the complex interplay of cultural norms. Consequently, women leaders' professional experiences become scripted by their position as women in their micro-cultures. Even when in leadership roles, cultural and belief systems redefine leadership for women, deterring them from identifying with the role of leader (Al-Khalifa 1992), as explained by a participating woman leader:

The culture in our country is to limit the women within their houses; their movements have to be in accordance with the cultural expectations even when professional demands are otherwise ... It creates problems. The women think of themselves more as Muslim women than managers and leaders. (PF1)

Blackmore (1995) argues for a de-construction of masculinist notions of leadership and invites us 'to question what is not included in the discourse as much as what is' ( $\mathrm{p}$. 96). The significance of gender with regard to female experiences across professions and societies make it important to take into account 'women's experiences of gendered power relations ..... [as] a source of knowledge' (Ramazanoglu 1993, p.209). It is recognition of the gender element and of power differentials instituted through given discourses, produced culturally and socially to exercise power, because:

As individuals, they cannot be separated from the society and culture in which they work and in which assumptions about men and women in public and private, in work or at family, prevail. (Hall 1996, p.12)

The roles of women leaders in Pakistan reflected these 'assumptions'. The leadership practices often conformed to the gender stereotypes in the wider social order. Women-only colleges offered aspiring women an opening of space in the public. However, the structural denominations inscribed the roles and practices, reinforced by the socio-cultural practices where 'traditional patterns of behaviours prescribe certain roles to which individuals, males and females, partially conform to differing degrees' (Blackmore 1995, p.121). The roles of female college heads were discursively constructed through historically inscribed discourses of what it was to be a Muslim, a woman, and in the 'domestic/public', according to given interpretations of religion in that culture:

I am a wife and mother first. The Quran says that it is my first responsibility to look after my family. I accept that, but at times it stretches me to the limit! 
Even when I have to work late in office, I cannot miss any of my domestic duties --- I am a woman. (PF3)

The simple statement at the end of the quote was made in a very matter-of-fact way, with no obvious inflections, but it clearly signals how leadership in the case of women is informed by cultural and belief systems.

\section{Family, Women and Leadership}

The women leaders participating in this study emphasised aspects of professional life where family affected their role and practices. In Islam, family is the basic social unit (Shah 2006a), which serves as a reference for rights and duties. Islam is very emphatic about significance of family and its priority in different matters. However, family in different societies and cultures 'remains a primary arena where men exercise their patriarchal power' (Hartmann 1981, p.377). This was reflected in the participants' responses who overwhelmingly believed that looking after their family was the first priority of a Muslim woman; therefore, they avoided taking any professional responsibility which could affect their family/extended family set up:

I am planning to give up principal-ship. Government is transferring me to another town, and my husband and in-laws don't agree with the move. It will affect children also. My father-in-law is old and I have to look after him as well. The in-laws and even other relatives will criticise that I am after career and do not care for family responsibilities. Family comes first --- How can I choose to continue? (PF6)

A nurturing responsibility towards the 'family' encouraged prioritising of domestic role to the extent of a willing acceptance of confinement to the domestic through given interpretations of the notions of motherhood and family (Brock et al 2006):

Women have responsibilities of family and children. We all wish to stay nearer to our homes so we could look after our homes. (PF4)

However, many scholars (Ahmed 1992, Badaawi 1994, Mernissi 1991) argue with reference to the religious texts that domestic responsibilities of Muslim women are not obligatory but optional. Siddiqi (1996) emphasises that 'According to strict Islamic injunctions, it is not obligatory for a woman to cook the food for her husband or children, or to wash their clothes or even to suckle the infants' (p.57). It is argued that emphasis on domestic role of women is culturally produced and not a religious proclamation. Raj (1982) mentions complaints by Indian women (mostly Hindu by faith) about combining home and job duties, and its being a barrier to professional progression, which emphasises cultural orientation of these gender related issues. Traditionally, family has served as a convenient space for exercising control, with specific implications for gender. In Pakistani culture, intricate networks of relationships and obligations in the family virtually deprive women leaders of professional power in the name of family. Islamic teachings and injunctions regarding the immediate and extended family are reinforced by the local patterns of behaviour concerning family and over-riding 'family obligations' (Shaw 1988, p.165): 
A lecturer's post has been advertised for my college. I as principal am to sit on the selection committee. My in-laws have asked my husband to get a particular candidate appointed. My dilemma is that the person does not qualify ... if I get her appointed it is professionally incorrect and if I don't get her appointed then my family life will be misery ... you know my husband being told that his wife does not listen to him. (PF9)

By deploying socio-cultural discourses and practices, family is converted into a space of oppression. For the women college heads leadership meant the intricate balancing of family/extended family priorities and wishes, and professional responsibilities in the face of all the challenges posed in a feudal, patriarchal, segregated society. However, paradoxically, the dilemma of a public activity such as educational leadership in a segregated society is resolved to some extent in the case of women college heads by re-inventing the site as 'family' and re-locating it within the domestic:

The college is a family, an extended family. The head has to manage the same way as a family head, treating each one according to one's positioning. (PF3)

This re-invention aimed at appropriating power through reverse discourses of family and motherhood. Motherhood emerges as a position of power in the network of relationships, with particular emphasis on the status of mother (Badaawi, 1994; Abdalti, 1994). By constructing colleges as 'family', the 'excluded' 'segregated' women college heads moved into a discourse where they could lay claims to power and authority as mothers, sanctified by the Quran and the Hadith:

We are like a family. When there are problems we discuss them within family. I have suggested a theory to my staff: when a student comes to you treat her as your own child and deal accordingly. (PF11)

Apparently they felt safer and stronger in managing the institutions, students and staff from a position of status and authority within the religious discourse. Whether they experienced balancing of different roles as 'a source of pressure' (Al-Khalifa 1992, p.96) or not assumes secondary significance in view of the empowerment achieved through fusion of the personal and the professional. Although in many Muslim societies, women appear to be deprived of their religious rights in the name of family peace and interest (Afshar 1987, p.132), the research participants highlighted advantages associated with the institution of family. Family provided a sense of social security in a cultural context where moving into public space was discouraged as unIslamic, with threats of social victimisation:

Staying close to family protects you from social victimisation. You know how difficult it is for women to work in positions like this. You have to communicate with men and influential people. And what our society is like! Having a strong family helps - people are careful in talking about you, and listen to what you have got to say even though you are a woman. (PF2)

Family was the safe heaven providing a reliable network and a source of protection, in spite of all associated cultural connotations of responsibility, constrained decision making, limited mobility, marginalisation and segregation. 


\section{Sex-segregation/Veiling and Leadership}

Leadership is underpinned by visibility, while veiling and segregation aim for invisibility. The essential tension between the two makes it a challenge to define female leadership in segregated societies. However, the participating Muslim women leaders did not see the two as contradictory, although they did acknowledge it as a significant factor shaping female leadership roles as well as posing certain challenges in practice. The nature of sex-segregation in Islam and how it is practised in Muslim societies is a complex debate. The rhetoric emphasises it as an Islamic injunction, but in the sacred texts it is a relative concept recommended so far as it is essential to maintain the social fabric of a Muslim society (Shah 2007). Islam discourages mixedsex settings because of its potential threat to Islamic societal structure, and provides a moral code for men and women operating in the public space (the Quran, Sura 4). Veiling is also linked to the value of modesty in Islam, and although its essential principles apply to both men (the Quran, 24:30) and women (the Quran, 24:30), 'double moral standards' for men and women (Afshar 1994), and culturally constructed practices of segregation create given discourses of veiling (for details concerning 'veiling' in Islam see Abdalti 1994, Afshar 1994, Ahmed 1992, Maududi 1995, Mernissi 1991, Siddiqi 1996) and associate those with women, problematising their participation in the public.

Women colleges in Pakistan are officially termed zanana (for women) colleges while colleges for men are called mardana (for men). The construction of women-only colleges as zanana shifts the site from the public to the domestic/familial/private with all the associated connotations of power differential, and:

Men get angry if a woman is appointed in a senior position mainstream. Their stand is that women should be selected for women only posts but not for opento-both ones... As long as we are in subordinate positions, there is no problem. (PF1)

The Muslim women in powerful leadership positions feel powerless because of the cultural 'gendered ideological foundation of authority' (Luke 1996, p.289). For example, these principals officially have powers as 'drawing/dispersing officers', but in practice all matter related to purchases, invoicing, bills and payment are delegated to the accountants because finance offices and banks are the 'male domains' (mardana). For a woman it would be a violation of social norms to move into 'male domains', and here cultural/belief systems determine the role and domain of a woman college head:

I wish there was a way that we could deal directly [and not through the clerks] with the banks. Our women managers suffer a lot because of social norms and pressures. It is inappropriate for women to visit banks or other male offices. (PF5)

A woman principal has 'to think a few times even before deciding to visit a male dominated public space on her own' (PF1). Some did mention that they went to these male offices occasionally, but accompanied by a male member of the family for the sake of appropriateness. Power differentials and gender demarcations, legitimised in the name of religion and culture, defined a gendered concept of leadership in a society 
that practised and approved sex-segregation. Structural constraints such as all-male offices and predominantly male support staff, cultural traditions of male supremacy, and the religious notion of sex-segregation interacted to formulate a specific concept of female leadership for these Muslim women. They often chose to be low profile, self-effacing and complying, 'seen but never heard' (Belenky 1986, p.32), a consequence of both self-policing and social control (Foucault 1980). Although women leaders appear to have different ways of coping with powerlessness' (Lamphere 1994, p.220), that does not mitigate the issues of de-voicing and silencing. The following quote from one female college head illuminates the point:

In general, attention is not paid to women's words. Their opinion regarding any official matter is not given that weight as a man's word. Then, being a woman, it does not seem appropriate to argue with men. (PF3)

Women leaders confined into the private space of girls' colleges, appear to be disciplined by the patriarchal norms and given religious discourses. An interesting story relevant here was narrated by one participant:

The secretary education was to preside over the Annual Prize Distribution in a male college. The local divisional director colleges (DDC), a female (the first woman divisional director colleges), was not invited by the college principal to that ceremony, contrary to the usual practice. When it was brought to the secretary's notice, he advised the lady (DDC) on phone to be present at the occasion. She went to the college at the appointed time ... The principal was angry to see her and told her rudely that no seating arrangements had been made for women.

A female educational leader who is in immediate authority over the male principal is denied a professional right and a simple human courtesy because of her gender. The fact is that women bring their femaleness with its connotations and status in society with them when they enter professions. There is no doubt that patterns of power and subordination are not just gendered, they are also cut across and transformed by class and other social formations (Weiner 1990). Feudal patriarchal orientation of Muslim societies in general (Ahmed 1992), and the given interpretations of sexuality and family law in Islam appear to strengthen patriarchal practices (Mernissi 1991), subjecting women to segregation and veiling which negatively affect their participation in the professional space.

Sex-segregation draws on the Islamic discourses of sex, chastity and morality. Chaste women keep away and 'veiled' from men except mehrams (Shah 1998). This had implications for the women college-heads confined to the zanana colleges, who had positional power and authority but it was limited to the segregated site. Paradoxically, women heads of zanana colleges also felt protected by the 'walls and veils', which kept the intruders out (Helms 1995). This provided women leaders a space in which to manoeuvre without the threat of open interference and blatant pressures. In spite of the obvious disadvantages such as issues of mobility, socio-professional net-working, barriers to career progression, and many others the women leaders felt advantaged by the comparative protection of the zanana, conforming to a concept of female leadership underpinned by cultural and belief systems. 


\section{Gendered Moral code and Concept of Izzat}

Izzat is a powerful discourse that determines women leaders' professional practices and roles in Pakistan. The term embodies enormously powerful cultural judgements. Females are expected to uphold the honour of the family, community and almost everyone else, through a strict maintenance of an honour code defined often by males. These honour codes are gender discriminatory and highly marginalising for women, promoting male control by subjecting women to 'surveillance' and 'disciplining' (Foucault 1980). The research participants consistently referred to observance of Islamic moral code and values while defining leadership for Muslim women. However, the discourse is manipulated to 'blackmail' women into silence and invisibility:

We and our girls are responsible for family izzat. A breath of scandal and that not only ruins your professional future and career but also upsets family life even destroys it. That is a stigma, and a woman with this stigma gets sidelined in the professional field as well. You become excluded - at home and in the profession. Better play it safe --- keep your head bowed and protect your izzat.

Muslim societies often proclaim to follow a specific moral code which they term as Islamic moral code, and assert that it derives from the Quran and the Sunnah. The Quran recommends basic principles of a moral code and the life of the prophet as model (the Quran, Sura 33) to all its followers regarding how to conduct themselves morally and socially. However, diverse interpretations of this moral code are structured in different Muslim societies. The high emphasis on values of modesty and chastity in Islam is often constructed socially as gender-specific. These values are linked to family honour (Izzat) and women are made into bearers of these values. The notion of Izzat (honour) draws from the Quranic teachings (17:23-24; 31:14-15; 46:15), but in practice, it is defined by cultural systems. By making women solely responsible for izzat (Afshar, 1994, p.129), it is given a gendered description which has serious implications for women operating in the professional and the public. Broadly speaking, the notion of izzat for women implies acceptance of prevailing social norms: submission to the male authority (Weiss 1994) in all matters concerning personal, professional, social, economic and others; capitulation to restricted/proscribed mobility; observance of sex-segregation; and, withdrawal from the public. Women leaders performed under high pressures because of the societal norms and the associated fear of 'gossip', 'scandal' and character assassination'. They preferred to remain 'invisible in the interest of family izzat' (PF3), and often left visible mainstream leadership positions for men. They believed that the risks involved in moving across the boundaries were too many:

If you are a woman, you would be immediately labelled as immoral. If a male visits your office a few times consecutively, you would be declared having an affair with him. I once travelled for an official meeting with a married male college head, and there was another male colleague in the car. I stayed in a women's hostel and returned with a family. When I got back, I learned that a local paper had published a news item about my affair and engagement with that head. ... It is a serious problem [for women]. The norms in our society permit men to do any thing ... that is all OK. ... The moral standards for men and women are the same in Islam, but there are immense social pressures [for 
women]. If a women's reputation is affected no one would marry her; and it would affect her career also. (PF11)

The fear of interpretations and consequences to family izzat effectively discouraged not only movements but also communications across the boundaries. Women were disciplined into segregation and silence in anticipation of the possible social threats. Even communication by telephone had to be culturally appropriate, requiring a circumscribed use of the facility:

Being a woman principal, I occasionally do face problems. Then I talk to the concerned male personnel on phone. If the problem is not solved I have to make a second call; but there would be a hijab (hesitation) this time. I find it a bit difficult to talk to men on phone. [sic] I intentionally try to avoid the situation. (PF4)

The skewed codes of conduct constructed by male authority posed threats to women leaders who may chose to move in the positions of visibility. Participation in the public was made into a challenge as attributes like 'seditious, corrupt, or prostitution' were 'granted freely to women but not to their male 'accomplices" (Afshar 1987, p. 74). According to the research participants, localised social and behavioural norms marginalised women because being women they were easy victims to 'social indictment'. Character assassination emerged as a tool paradoxically linked with the notion of izzat. Women felt that they were often playing in a defensive position, as one participant angrily complained:

If a woman works with male colleagues, there is a scandal. There can be relationships without corruption! (PF8)

An effective leadership role was premised on being perceived as a good Muslim woman of moral values and character; however, what it meant to be a good Muslim woman was vague and subjective.

\section{Framing Gender, Leadership and Muslimness}

Educational leadership for women in Pakistan is framed in a discourse of Muslimness. How these Pakistani Muslim women understand and define educational leadership is informed by the relevant cultural and religious belief systems - what it means to be a good Muslim as understood and interpreted in that culture. I am not implying any hegemonic discourse of Muslimness. My argument is that concepts and practices are located in contexts, and these constructions take place at the interstices of interacting variants. What educational leadership means for Muslim women leaders can not be de-linked from their Muslimness and associated culture. A stepping outside the dominant religious and cultural discourses may not be good for their sense of self, and probably for the leadership practices as well. Conversely, the risk is the way interpretations become monopolised and fixed. In such situations, the need increases for un-fixing, re-negotiation and re-interpretation of discourses with a view to understand situated concepts and practices.

Sex-segregation is generally critiqued as depowering and marginalising for women. For my research participants, it created a space for exercising leadership in the 
domain of women-only institutions. However, the concept and practices of leadership were redefined in accordance with the cultural and belief systems for the sake of cultural appropriateness and religious legitimisation. The women leaders did not perceive the religious norms of conduct problematic for their professional role. However, separate patterns and standards of conduct/character applied to men and women were socially endorsed as propounded by Islam; and women, by not having access to places of interpretation submitted to those, which had serious implications for their professional roles specifically with regard to participation in the public, and personal and professional mobility. Bernstein's in his interesting discussion of knowledge and control states:

The way a society selects, classifies, distributes, transmits, and evaluates educational knowledge reflects both the distribution of power and the principles of social control. (1977, p.47)

The management practices of the college heads were underpinned by the religious, socio-cultural, and professional discourses. The women educational leaders in this context performed within the gender discourse which, in this case, had its roots in interpretations of religion and the status of women in Islam. These appeared to be deliberately wielded and indicated 'how truth is implicated and deployed in social practices and how 'regimes of truth' can have profound social and cultural consequences' (Beechy and Donald 1985, p. xiv). These discourses opened discursive fields to the Muslim women college heads to position and redefine themselves. The discourse of human equality in Islam (the Quran, 3:195; 4:1; 4:124; 33.35; 49:13) encouraged women leaders to seek career progression and professional participation but a counter 'cultural' discourse of gender difference imposed constraints. Movements within and across the discourses of gender, culture and religion were situation-determined, and continuously changed priorities. This endorses that an analysis and theorising of roles and practices needs to be worked within the parameters of these constructed discourses, informed by cultural and belief systems.

\section{References}

Abdal'ati, H. (1994) Islam in Focus. The Ministry of Awqaf and Islamic affairs; (Doha-Qatar: Arabian Gulf).

Abdullah, A. S. (1982) Educational Theory: A Quranic Outlook (Makkah. Saudi Arabia :Umm-Al-Qura University).

ADB Report (2000) Situational Analysis of Women in Pakistan - an overview. Country Briefing Paper (Asian Development Bank).

Adler, S., Laney, J. and Pasker, M. (1993) Managing Women (Buckingham: Open University Press).

Afshar, H. (1987) Women, Marriage and the State in Iran. In H. Afshar (ed) Women, State and Ideology. (London: Macmillan Press) pp. 70-86.

Afshar, H. (1994) Muslim Women in West Yorkshire, in H. Afshar and M. Maynard (eds) The Dynamics of Race and Gender: Some Feminist Interventions.

(London: Taylor and Francis) pp. 127-147.

Ahmed, A. S. and Donnan, H. (eds) (1994) Islam, Globalization and Postmodernity. (London:Routledge). 
Ahmed, L. (1992) Women and Gender in Islam: Historical Roots of a Modern Debate (Yale University Press).

Al-Attas, M. (1979) Aims and Objections of Islamic Education (Hodder and Stoughton).

Al-Bukhari, S. M. Sahih al-Bukhari Vol. 1. Translated by Dr. Muhammad Muhsin Khan (Lahore: Dar-us-Salam Publications).

Al-Hibri, A. (ed) (1982) Women and Islam. Published as a special issue of Women's Studies International Forum, 5(2), (Oxford: Pergamon Press).

Al-Khalifa, E. (1992) Management by Halves: Women Teachers and School Management, in N. Bennett; M. Crawford and C. Riches (eds) Managing Change in Education (London: Paul Chapman and OUP), pp. 95-106.

Ashraf, S. A. (1995) Basic Principals in the Formulation of Curriculum for Tertiary Education with Specific Reference to Humanities, in Muslim Education Quarterly 13(1), 5-11.

Badawi, L. (1994) 'Islam', in J. Holm with J. Bowker (eds) Women in Religion. (London: Pinter Publishers), pp. 84-112.

Bauman, Z. (1997) Postmodernity and its Discontents. (Cambridge: Polity).

Beechey, V. and Donald, J. (eds) (1985) Subjectivity and Social Relations: A Reader. (Milton Keynes: OUP).

Belenky, F. M. et al (1986) Women's Ways of Knowing: the development of self, voice, and mind. (New York: Basic Books).

BenHabib, S. (1992) Situating the Self: Gender, Community and Post-Modernism in Contemporary Ethics (Cambridge: Polity Press).

Bernstein, B. (1977) Class, codes and control. Vol. 3, Towards a theory of educational transmission; 2nd rev. ed. (London: Routledge and Kegan Paul).

Blackmore, J. (1995) Educational leadership: A feminist critique and reconstruction, in J. Smyth (ed) Critical Perspectives on Educational Leadership (London: Cassell), pp. 93-129.

Blackmore, J. (1999) Troubling Women: Feminism, leadership and educational change (Buckingham: Open University Press).

Bourdieu, Pierre and Passeron, Jean-Claude (1977) Reproduction in education, society and culture. (London: Sage).

Busher, H. (2006) Understanding Educational Leadership: People, power and culture. (Maidenhead: Open University Press).

Child, J. (2003) Theorising about organisation cross-nationally: part 2. In M. Warner and P. Joynt (eds) Managing across cultures: issues and perspectives, (London: Thomson Learning), pp. 40-56.

Curry, B.K. (2000) Women in Power: Pathways to leadership in education; Foreword by Maxine Greene. (Boston: Teachers College Press).

Davies, L. and Gunawardena, C. (1992) Women and Men in Educational Management: an international enquiry. (Paris: IIEP).

Derrida, J. (1976) Of Grammatology. Tr. by Gayatri Chakravorty Spivak. (Baltimore: John Hopkins University Press).

Dimmock, C. (2000) Designing the learning-centred school: a cross-cultural perspective (London: Falmer Press).

El-Saadawi, N. (1982) Women and Islam, in Al-Hibri, A. (ed) Women and Islam. (Oxford: Pergamon Press), pp. 193-206

Esposito, J. L. (2002) Unholy War: terror in the name of Islam. (Oxford: Oxford University Press). 
Farouk, U. K. (2006) Gender in Management: the case of Malaysian women, in Proceedings of International Conference on Social Sciences: endangered and engendered pp. 441-459.

Foucault, M. (1980) Power/Knowledge: Selected Interviews and Other Writings, (1972-1977) (Brighton: Harvester Press).

Fullan, M (1992) What Is Worth Fighting For In Headship? Strategies for Taking Charge of the Headship. (Buckingham: OUP).

Geertz, Clifford (1973) Religion as a Cultural System, In ????(ed) The Interpretation of Cultures (NY: Basic Books).

Gold, A. (2006) Women, Leadership and Values, in Proceedings of International Conference on Social Sciences: endangered and engendered, Dec 10-12, 2004, at Fatima Jinnah Women University (FJWU) in collaboration with Higher Education Commission (HEC) Pakistan, pp. 17-39.

Gray, M. M., Kittilson, M. C. and Sandholtz, W. (2006) Women and Globalization: A Study of 180 Countries, 1975-2000, International Organization 60, 293-333.

Griffin, R. (2006) Education in the Muslim World: different perspectives. (Symposium Books).

Hall, V. (1996) Dancing On The Ceiling: a study of women managers in education. (London: Paul Chapman Publishing)

Hartmann, I. H. (1981) Family as the locus of gender, class and the political, Signs; 6, 366-394.

Helms, L. M. (1995) The Haram as a Sacred Space for Muslim Women, Muslim Education Quarterly, 12(3), 62-72.

Hey, V. and Bradford, S. (2004) 'The Return of the Repressed?: the gender politics of emergent forms of professionalism in education'. Journal of Education Policy, 19(6), 691-713.

Hofstede, G. (2001) Culture's Consequences, $2^{\text {nd }}$ edition. (London: Sage Publications).

hooks, b. (1990) Yearning: race, gender, and cultural politics. (Boston: South End).

Kirdar, S. (2006) The Development of Women's Education in the Arab World', in R. Griffin Education in the Muslim World: different perspectives (Symposium Books), pp. 191-210.

Lamphere, L. (1994) (Response) Expanding our notions of 'critical qualitative methodology': Bringing Rrace, class, and gender into the discussion', in A. Giltin (ed) Power and Method: political activism and educational research. (London: Routledge), pp. 217-224.

Luke, C. (1996) Feminist Pedagogy Theory: Reflections on Power and Authority Educational Theory, 46(3), 283-302.

Maududi, S. A. A. (1995) Purdah and the Status of Women in Islam. (Lahore Pakistan: Islamic Publications Ltd).

McClain, L. (2007) Wisdom-centred leadership in Education: practices of the Bodhisattva leader, Paper presented at the UCEA Conference, Nov 2007, Washington.

Mernissi, F. (1991) Women and Islam: a historical enquiry. (Oxford : Basil Blackwell).

Mullins, L. J. (1995) Management and Organisational Behaviour. (London: Pitman).

Niaz, S. (1992) Un-kaahi Dastan-e-Kashmir (Untold Story of Kashmir) (Lahore, Pakistan:Classic).

Nasr, S. H. (1981) Islamic Life and Thought. (London: Allen and Unwin). 
Nayyer, U. (1985) Women in educational management in Third World countries: The Indian case study, in D. Marshall and E. Newton (eds) The Professional Preparation and Development of Educational Administrators in Developing Areas, Proceedings of CCCA/CEASEA Conference.

Ono, S (1962) Shinto, The Kami Way. (Tuttle: Prentice-Hall).

Oplatka I. and Hertz-Lazarowitz, R. (eds) (2006) Women Principals in a Multicultural Society:_New Insights into Feminist Educational Leadership. (Rotterdam: Sense Publishers).

Oplatka, I. (2001) I changed my management style: The cross gender transition of women head teachers in mid-career. School Leadership and Management, 21(2), 219-233.

Ouston, J. (ed) (1993) Women in education management. (Harlow, Essex: Longman).

Ozga, J. (ed) 1994, Women in Educational Management. (Buckingham: Routledge).

Polanyi, M. (1967) The Tacit Dimension. (London: Routledge).

Pugh, D. S. and Hickson, D. J. (2003) On organisational convergence, in M. Warner and P. Joynt (eds) Managing across cultures: issues and perspectives, (London: Thomson Learning), pp. 7-12.

Qureshi, S. (2004) Pakistan: Education and Gender Policy; Girl's Education: a lifeline to development. Research Paper by Sabina Qureshi, IPF Fellow (2003-4). Online http://www.policy.hu/qureshi/Respaper.pdf

Raj, M. K. (1982) Women, Work and Science in India, in G. P. Kelly and C. M. Elliot (eds)Women's Education in the Third World: Comparative Perspectives. (Albany: State University of New York), pp. 249-263.

Ramazanoglu, C. (ed) (1993) Up against Foucault: explorations of some tensions between Foucault and feminism. (London: Routledge).

Reay, D. and Ball, S. J. (2000) Essentials of Female Management. Educational Management and Administration, 28(2),145-159.

Richmon, M. J. and Allison, D. J. (2003) Towards a conceptual framework for leadership inquiry, Educational Management Administration and Leadership, 31(1) 31-50.

Sergiovanni, T. J. (1984) Leadership and excellence in schooling'. Educational Leadership, 41(5), 4-13.

Shah, S. and Conchar, C. (2007) Single-Sex Education Provision in Nottingham City. Research Report: Nottingham City Council, Children's Services. Online, www.nottinghamcity.gov.uk/education

Shah, S. (1998) Flash-backs-and-forth: Researching the roots', in K. Haw with S. Shah Educating Muslim Girls: Shifting Discourses. (Buckingham: OUP), pp. 4362.

Shah, S. (1999) Education Management: braving boundaries. (Islamabad: National Book Foundation).

Shah, S. (2006a) Leading Multiethnic Schools: a new understanding of Muslim Youth Identity, Journal of Educational Management, Administration and Leadership; Special Edition on Leadership and Diversity 34(2), 215-237.

Shah, S. (2006b) Educational Leadership: an Islamic perspective. British Educational Research Journal, 32(3), 363-385.

Shakeshaft, C. (ed) 1991, Women in Educational Administration. (Newsbury Park: Sage Publication).

Shaw, A. (1988) A Pakistani Community in Britain. (Oxford: Basil Blackwell).

Siddiqi, M. (1996) Women in Islam. (Lahore, Pakistan: Institute of Islamic Culture). 
Skeggs, B. (2004) Class, Self, Culture.(London, Routledge).

Spencer, A. and Podmore, D. (1987) In a Man's World: essays on women in maledominated professions. London: Tavistock

Strachen, J. (1993) 'Searching Women in Educational Leadership', in Gender and Education: 5(1), pp. 71-80

Talbani, A. (1996) 'Pedagogy, Power, and Discourse Transformation of Islamic Education', in Comparative Education Review; 40(I) pp.66-82.

Tung, R. L. (2003) 'Managing in Asia: cross-cultural dimensions' --- in Warner and Joynt (eds.) op cit; pp 137-142.

Walker, A. and Dimmock, C. (2002) 'Cross-cultural comparative insights into educational administration and leadership', in A. Walker and C. Dimmock (eds.) School leadership and administration: adopting a cultural perspective, London, Routledge Falmer, pp 13-32.

Weber, M. (1963), The Sociology of Religion, Boston, Beacon Press.

Weber, M. (1958) From Max Weber: Essays in Sociology. Edited by H. H. Gerth and C. W. Mills New York: Oxford University Press.

Weiner, G. (ed) 1990, The Primary school and equal opportunities: international perspectives on gender issues. London: Cassell.

Weiss, A. M. (1994) 'Challenges for a Muslim Woman in a Postmodern World', in A. S. Ahmed and D. Hastings (eds) Islam, Globalization and Postmodernity. London Routledge; pp 127-140.

Wilson, F. M. (1995) Organizational behaviour and gender; foreword by Gibson Burrell. London: McGraw-Hill.

Wilson, M. (ed) 1997, Women in Educational Management: A European Perspective. London: Paul Chapman.

Wong, Kam-Cheung (2001) Chinese culture and leadership. International Journal of Leadership in Education, 4(4) pp. 309 - 319

Yukl, G. A. (1998) Leadership in Organizations, Prentice-Hall, Englewood Cliffs, NJ. 